(Mikulas \& Isaacson, 1965), the caudate rats of this study did not begin perseverating until after many postoperative trials.

Individual records of the caudate rats in Light-approach were investigated for any correlation between the preferred side postoperatively and any of the following: the side the rat was trained to preoperative$1 y$, the preferred side on the first 15 trials preoperatively, the side the rat went to on the first trial preoperatively, and the preferred side on the first 5 trials postoperatively. None of these showed significant correlation. There was only a slight tendency for postoperative preference to be correlated with the preoperative training side.

A common effect lasting a few days following caudate lesions is a persistent turning toward the side of the greater lesion. Only one of the caudate rats showed any turning and it had little preference for either side in the postoperative task.

Histological examination revealed no significant differences in the size or place of lesions between the two caudate subgroups. Nor was there a correlation between the size or place of lesion and the degree of perseveration.

\section{DISCUSSION}

A spatial alternation task (Mikulas, 1966) found that the presence of a choice-point light on the side of the correct arm improved the performance of caudate-lesioned rats. In the present study, using the same apparatus, the caudate rats showed a deficit when required to go toward the side with iluminated light and no deficit when required to go to the side opposite the light. In the present study the rat must attend to the light for correct performance, while in the alternation task the rat could have errorless performance without attending to the lights. Also the postoperative tasks of the present study are probably more difficult for a rat than an alternation task.

The lights may be slightly aversive to the caudate rat. This may be specific to these stimuli or may be because the lights are novel relative to preoperative training. If the lights are aversive, it suggests the following hypothesis: In simple tasks (e.g., spatial alternation) where an aversive stimulus is not a necessary discriminative stimulus, the stimulus may disrupt perseverative tendencies in caudate rats and hence improve their performance. While in more complex tasks where the aversive stimulus is a necessary discriminative stimulus, requiring the caudate rat to approach the stimulus may augment perseveration tendencies.

A second possibility is that since during preoperative training the lights were not on, the rats may prefer the unlit sides postoperatively. This would produce no conflict in task Light-avoid but would in task Light-approach. And this conflict may produce more perseveration in caudate rats than controls, perhaps because they are more easily frustrated and hence fixate some response (Maier, 1949).

The present experiment has not revealed any way of predicting toward which side the animal will perseverate. Perhaps more intensive preoperative training would have a more determining effect on postoperative preferences.

\section{REFERENCES}

DeGROOT, J. The rat forebrain in stereotaxic coordinates. Verh. Kon. Ned. Akad. Wet., B. Natuurkunde, 1959, 52,140.

MAIER, N. R. F. Frustration. New York: McGraw-Hill, 1949.

MIKULAS, W. L. Effects of lights at the choice point on spatial alternation and position learning by normal rats and rats with bilateral lesions of the caudate nucleus. Psychonomic Science, 1966, 5, 275-276.

MIKULAS, W. L., \& ISAACSON, R. L. Impairment and perseveration in delayed tasks due to bilateral lesions of the caudate nucleus in rats. Psychonomic Science, 1965, 3, 485-46.

SCHWARTZBAUM, J. S., \& DONOVICK, P. J. Discrimination reversal and spatial alternation associated with septal and caudate dysfunction in rats. Journal of Comparative \& Ptysiological Psychology, 1968, 65, 83-92.

NOTE

1. The study was supported in part by a USPHS predoctoral fellowship to the author (5-F 1-MH-29, 114-02) and in part by a USPHS grant to J. D. Papsdorf (MH 12504-01). The author would like to thank Dr. Papsdorf for his support and assistance.

\title{
Novelty as a basis for the reinforcing effects of saccharine'
}

\author{
NISSIM LEVY ${ }^{2}$ and DALE R. TURNER, ${ }^{3}$ \\ University of Portland, Portland, Oreg. \\ 97203
}

The purpose of this experiment was to test the hypothesis that the reinforcing effects of saccharine could be, at least in part, understood in terms of stimulus change. Four groups of 20-day-old rat pups were used as Ss. Half of them were reared on $1.3 \%$ saccharine solution, and half on tap water for 2 months. At 88 days of age, straight-alley training was given under $a 3-h$ thirst deprivation. Single daily trials for 21 days were received. Half of the saccharine-reared $S s$ found I-cc saccharine solution as a reward; half of them found tap water, and similarly for the water-reared Ss. Water-reared Ss ran faster to the saccharine solution, and saccharine-reared Ss ran faster to water than their respective controls.

A phenomenon which has been a puzzle to psychologists for years revolves around the reinforcing qualities of saccharine. Saccharine is a chemical which tastes sweet to human beings, and does not seem to have any nutritive or caloric value as it passes through the organism unaltered. Animals consuming saccharine do not diminish their food intake (Hausmann, 1933). Despite the fact that saccharine has no nutritive value, animals will run mazes, press bars, and perform other instrumental acts when rewarded with it (Carper, 1953; Sheffield, Roby, \& Campbell, 1954). This is in direct opposition to the definition of a primary reinforcer as proposed by Hull (1943) and Miller \& Dollard (1941).

There have been a number of attempts to explain this instrumental responding in the absence of primary reinforcement. Sheffield \& Roby (1950) feel that the possibility of saccharine having an acquired or secondary reward value is negligible as an explanation of their findings.

Experiments by Guttman (1954), and Hagstrom \& Pfaffman (1959) have shown that instrumental response rate is related to the concentration of the solution. Sheffield \& Roby (1954) feel that sweet stimulation innately elicits ingestion.

Nachmann (1959), by means of selective breeding, has produced strains of rats with a strong saccharine preference. Nachmann (1957) has also found that the animals raised on saccharine drink less saccharine during testing than the animals raised on water.

A number of investigators have shown that novel stimulation or, more carefully put, "stimulus change" can serve as a reinforcer (Berlyne, 1950; Chapman \& Levy, 1957; Glanzer, 1953, 1958). These data, toge ther with Nachmann's observation noted above, suggested to us the possibility of accounting for the reinforcement effects of saccharine in terms of novelty. If novelty is operating, we should find that animals raised on saccharine would find water, following an instrumental response, more rewarding than saccharine.

The purpose of the present experiment was to test this hypothesis.

\section{SUBJECTS}

The Ss for this experiment were 40 male albino rats purchased from the Northwest Rodent Company, of Pullman, Washington. They were of weaning age (approximately 20 days old) on arrival and were about 88 days old at the time of testing.

\section{APPARATUS}

The apparatus was composed of a start box (SB), two alleyways (A1, A2), and two goal boxes (GB 1, GB2) arranged in tandem. The start box and both goal boxes were equipped with guillotine doors. The start box was $12 \times 3 \times 5 \mathrm{in}$. and both goal boxes 
were $16 \times 6 \times 5$ in. The alleyways were $144 \times 3 \times 5$ in. Each GB had a reward cup located in the right corner as $S$ entered. The tops of the alleyways were made of hinged wood with $1 / 4$-in. wire mesh set into them. The tops of the goal boxes were also made of hinged wood and $1 / 2$-in. wire mesh set into them. Al and GB 1 were painted flat black, while $A 2$ and GB2 were painted flat grey. All floors were smooth painted wood.

Running time (RT) was measured by using three standard electric timers connected to photocells located $1 \frac{1}{2} \mathrm{in}$. above the maze floor. The first cell was in A1, 8 in . from the SB door. The second cell was 3 in. inside GB1. There were two cells in $A 2$, one 14 in. from the door of GB1 and the second 134 in. from the door of GB1. This particular apparatus was employed to facilitate the use of these animals in a subsequent experiment.

\section{PROCEDURE}

Immediately upon arrival the Ss were randomly assigned to one of four groups with an equal $\mathrm{N}$ limitation. The first group (WW) was raised on wafer and tested on water; tile second (WS) was raised on water and tested on saccharine; the third (SS) was raised on saccharine and tested on saccharine; and the fourth (SW) was raised on saccharine and tested on water. Shortly after arrival two animals died; this reduced the $\mathrm{N}$ of the WW and WS groups to nine. Ss were housed in large living cages throughout both the rearing and testing periods.

All Ss were given ad lib food and either water or saccharine water in their home cages during the entire experiment. The saccharine water was a $1.3 \%$ solution, which is the same as that used by Sheffield \& Roby (1954). After 60 days, and 7 days before training proper began, $S s$ were placed on a 3-h deprivation schedule. This was done to insure that the animals would sample the reward liquid and to avoid the possibility that the animals would be responding as a result of a strong thirst drive.

During the first 5 days of $3-\mathrm{h}$ water deprivation, Ss were placed in the apparatus in pairs and allowed to explore freely for a 6-min period so that they could adapt to opening and closing the guillotine doors and to hearing the noises of the timing mechanism. On the last 2 days of this period, Ss were placed in GB1 and GB2 for 2-min periods. Each food cup contained $1 \mathrm{cc}$ of whichever liquid they had been reared on.

TRAINING

Each $S$ received one trial per day, for 21 days. Groups WS and SS found 1 cc of $1.3 \%$ saccharine solution in each goal box and Groups WW and SW found 1 cc of tap water in each goal box. Ss were kept in each goal box for $10 \mathrm{sec}$ after drinking. On being removed from GB2 they were returned directly to their home cages. Measures

recorded were $\mathrm{RT}$ for $\mathrm{A} 1, \mathrm{RT}$ for $\mathrm{A} 2$, and total RT (A1 and A2).

\section{RESULTS AND DISCUSSION}

Since all three measures used yielded the same pattern of results, only the data for total running time are presented. For purposes of statistical analysis, the median total RT for each S over the last six training trials was used as a score. One $S$ in the WW group developed strong fear reactions in the apparatus. His data were clearly deviant and his scores are not included in the analysis.

The purpose of the WW and WS groups was to demonstrate the typical reinforcing effect of saccharine. The mean total RTs for WW and WS groups were $18.47 \mathrm{sec}$ and $12.24 \mathrm{sec}$, respectively, yielding a $\mathrm{t}^{4}$ of 2.85 , which is significant at the $<.05$ level with $15 \mathrm{df}$.

Thus we see that, as might be expected, Ss reared and maintained on water who found $1 \mathrm{cc}$ of saccharine water in both goal boxes do, in fact, run faster than their controls, running to the same liquid they have in their home cages.

Now what do our crucial SS and SW groups show? The mean total RTs for SS and SW were $14.91 \mathrm{sec}$ and $11.59 \mathrm{sec}$, respectively, yielding a t of 2.24 , which for $18 \mathrm{df}$ is also significant at the $<.05$ level. Apparently, as our hunch suggested, plain tap water is a stronger reinforcer to $S s$ reared on saccharine than is saccharine.

These findings suggest that novelty or change in stimulation in the gustatory-sense modality is rewarding. Whether or not this factor can completely explain the reinforcing properties of saccharine is not certain. It is our belief that it can.

\section{SUMMARY}

This study addressed itself to two related questions: (1) Will saccharine solution serve as a stronger reinforcer than water for $\mathrm{Ss}$ reared on water? (2) Will water serve as a stronger reinforcer than saccharine solution for Ss reared on saccharine solution?

Four groups of Ss were used in this study: WW $(\mathrm{N}=8)$ reared on water, tested on water; WS $(N=9)$ reared on water, tested on saccharine solution $(1.3 \%)$; SS $(N=10)$ reared on saccharine solution, tested on saccharine solution; and $S W(N=10)$ reared on saccharine solution, tested on water.

Running times in a double-alley, doublegoal box apparatus were used as measures. Statistically reliable differences were found between WW and WS and between SS and SW in the same direction, i.e., Ss reared on water ran faster to the saccharine solution than to water, and Ss reared on saccharine solution ran faster to water than to the saccharine solution.

The results are interpreted as supporting a stimulus change basis for the reinforcing effects which have been noted for saccharine.

\section{REFERENCES}

BERLYNE, D. E. Novelty and curiosity as determinants of exploratory behavior. British Journal of Psychology, 1950, 41, 68-80.

CARPER, J. W. A comparison of the reinforcing value of a nutritive and a nonnutritive substance under conditions of specific and general hunger. American Journal of Psychology, 1953, 66, $270-277$.

CHAPMAN, R. M., \& LEVY, N. Hunger drive and reinforcing effect of novel stimuli. Joumal of Comparative \& Phy siological Psy chology, 1957 , 50, 233-238.

COCHRAN, W. G., \& COX, G. Experimental designs. (2nd ed.) New York: John Wiley \& Sons, 1957.

EDWARDS, A. L. Experimental design in psychological research. (Rev. ed.) New York: Rhinehart \& Co., 1960.

FISHER, R. A. The design of experiments. (5th ed.) Edinburgh: Oliver \& Boyd, 1949.

GLANZER, M. Stimulus satiation: Explanation of spontaneous alternation and related phenomena. Psychological Review, 1953, 60, 257-268.

GLANZER, M. Curiosity, exploratory drive, and stimulus satiation. Psychological Bulletin, 1958, $55,302-315$.

GUTTMAN, N. Equal reinforcement values for sucrose and glucose solutions compared with equal sweetness values. Journal of Comparative \& Phy siological Psy chology, 1954, 47, 358-361.

HAGSTROM, E. C., \& PFAFFMAN, C. The relative taste affectiveness of different sugars. Joumal of Comparative \& Physiological Psy chology, 1959, 52, 259-261.

HAUSMANN, M. F. The behavior of albino rats in choosing foods: II. Differentjation between sugar and saccharine. Journal of Comparative \& Physiological Psychology, 1933, 15, 419-428.

HULL, C. L. Principles of behavior. New York: Appleton-Century-Crofts, 1943.

MILLER, N. E., \& DOLLARD, J. Social learning and imitation. New Haven: Yale University Press, 1941.

NACHMANN, M. The influence of diet and age on saccharine preference in rats. American Psychologist, 1957, 12,461.

NACHMANN, M. The inheritance of saccharine preference. Journal of Comparative \& Physiological Psychology, 1959, 52, 451-457.

SHEFFIELD, F. D., \& ROBY, T. B. Reward value of a nonnutritive sweet taste. Journal of Comparative \& Phy siological Psy chology, 1950 , 43,471-481.

SHEFFIELD, F. D., ROBY, T. B., \& CAMPBELL, B. A. Drive reduction vs. consummatory behavior as determinants of reinforcement. Journal of Comparative \& Physiological Psychology, 1954, 47, 349-354.

\section{NOTES}

1. This research was supported by funds from NSF Grant No. G 10894 to Nissim Levy and John P. Seward.

2. Now at Howard University, Washington, D.C

3. This study was suggested by the senior author, who takes sole responsibility for this report. It was carried out by Mr. Turner as part of the requirement for the MA degree.

4. The reader may wonder why the data were not analyzed by means of a factorial design. We wish to point out that we are here following a dictum, subscribed to by statistical design authorities (Cochran \& Cox, 1957; Edwards, 1960; Fisher, 1949), which strongly suggests that statistical designs fit empirical questions, rather than empirical questions be raised which fit experimental designs. In this experiment, we are not addressing ourselves to the questions laid out by use of a factorial design. 